\title{
Review on Production and Importance of Basil (Ocimum basilicum L) and Roles of Fertilizer on Basil Yield
}

\author{
Getachew Jimayu \\ Ethiopian Institute of Agricultural Research (EIAR), Melkasa Agricultural Research Center, \\ P. O. Box 436, Adama, Ethiopia
}

\begin{abstract}
Basil (Ocimum basilicum L.) is one of the most popular medicinal and aromatic plants that belong to Lamiaceae family and the Ocimum genus is known with its highly aromatic leaves, utilized either fresh or dried for culinary. Basil is grown in many countries of the world as spice, medicinal, and aromatic plant. The medicinal and aromatic properties of basil are associated with the presence of an essential oil that accumulates in large amount in its leaves and inflorescences. It performs well in warm and humid climate. However, basil is sensitive to frost and heavy rain fall. The growth and yield of basil is affected by different factors. Moreover, nutritional requirements of the crop are considered to be the most important factor among many plant growth factors. Nitrogen contributes to greatest extent to increase the biosynthesis of essential oil and its composition in numerous aromatic plant species. Essential oil yield and its chemical composition of these plant species significantly depend on the rate of nitrogen, phosphorous and sulfur.
\end{abstract}

Keywords: Chemical composition, Essential oil, and Nitrogen.

DOI: $10.7176 / \mathrm{PPAR} / 11-9-05$

Publication date:May $31^{\text {st }} 2021$

\section{Introduction}

Among all Ocimum species, Ocimum basilicum L, is the most economic important, cultivated and utilized throughout the world (Marott et al., 1996). It occurs in nature as a tetraploid $(2 \mathrm{n}=48)$. Its taxonomy is further complicated by the existence of chemo-types or chemical races within the species that do not differ significantly in morphology (Simon, et al, 1990), Basil is used as fragrance ingredients in perfumes, hairdressings, dental cream and mouth washes. The leaves can be used in fresh or dried as spice. Essential oils extracted from fresh leaves and flowers can be used as aroma additives in food, pharmaceuticals and cosmetics (Javanmardi et al., 2002; Simon et al., 1999; Senatore, 1996).

Basil (Ocimum basilicum $\mathrm{L}$ is an annual plant of the Lamiaceae family. The genus Ocimum (Lamiaceae) consists of about 50-150 species (Simon et al., 1990). It is small bushy annual plant of about $60 \mathrm{~cm}$ in height and strongly aromatic herb. Leaves of basil are opposite in arrangement, ovate-lanceolate, $3.75-5 \mathrm{~cm}$ long, almost entire and possess numerous oil glands, which contain aromatic volatile oil; petioles very slender usually slightly hairy; flowers $0.72-1.25 \mathrm{~cm}$ long, born in racemose inflorescences, corolla, white, pink or pale-purplish, bracts are petiolated, flowers are conspicuous, seeds are black and ellipsoid which become mucilaginous on wetting (Darrah, 1980; Kumar, 2014).

Basil is herbaceous species, native to warm regions of Asia, Africa and India, but it is grown commercially all over the Mediterranean region and in California (Heath, 1981). According to Kumar (2014), basil was taken from India to Europe through the Middle East in the sixteenth century, and subsequently to America in the seventeenth century. The main centers of diversity of this genus are Africa, South America (Brazil) and Asia. It grows mainly in France, Italy, Bulgaria, Hungary, South America, Comoro Islands, Thailand, India, Haiti and Guatemala.

Essential and herb yield of basil are affected by different factors. Field experiments carried out on many essential oil bearing plants have shown that yield and composition of essential oil varies considerably by application of different fertilizers (Tiwari and Banafar, 1995). Among these fertilizers, nitrogen contributes to greatest extent to increase the biosynthesis of essential oil and its composition in numerous aromatic plant species. Therefore, the objective of this review is to assess the production and importance of basil and role fertilizer on growth and yield of basil (Ocimum basilicum L).

\section{Climatic and Soil Requirements of Basil}

Basil is easy to grow. It is a warm season herbs and consequently do not perform well under cool condition and it requires a minimum temperature of $10-15^{\circ} \mathrm{C}$. Basil plant requires full sun light for normal growth. It is suited to warm conditions and develops best under long days in sunny conditions. However, the optimum temperature for germination is between $21^{\circ} \mathrm{C}$ to $30^{\circ} \mathrm{C}$ (Putievsky, 1983).

The crop performs well in warm and humid climate up to an altitude of $1800 \mathrm{~m}$. It is susceptible to frost. It growth is poor in areas which receive heavy and continuous rainfall. In such areas the crop could be raised prior to the onset of rainy season and care should be taken that the rain water does not stagnate in the field (Joy et al., 
2001). Water logging causes root rot and result in stunted growth. Basil can be cultivated on a wide range of soils, from moderately fertile, well drained loamy to sandy loam soils with a $\mathrm{pH}$ ranging from $4.3-9.1$. While, clayey, water logged soils are not suitable. It is tolerant to high concentration of copper and zinc, but is susceptible to cobalt and nickel. (Joy et al., 2001; Kumar 2014).

\section{Major Cultural Practices of Basil}

Seedlings are prepared in nursery at least two months before transplanting. Minimum of two tillages are preferred. The field should be kept weed free for the first 20-25 days, till the crop canopy completely covers the ground. Weeding is usually carried out once or twice per required (Joy et al., 2001). In large plantation the expenditure on weeding can be minimized by the use of cultivator drawn by tractor. Irrigation is required once a week when it is raised during dry season (Hamasaki et al., 1994). After seedling is transplanted to the main field irrigation and other cultural practice such as weeding should be done as needed. Hoeing is done two months after planting (Kumar, 2014). According to the author the crop also need earthed up at this stage.

The basil crop is harvested at 90-95 days after transplanting at stage when plant lower leaves start turning yellowish. Time of harvest plays an important role in qualitative and quantitative oil production. Harvesting is usually done in bright sunny days for good oil yield and quality. It is not desirable to harvest the crop if there is rain during the previous day. Care should be taken while harvesting the basil to avoid any type of contamination at this stage. Clean all surfaces that come in to contact with the plants during and after harvest (Kumar, 2004).

Based on the part harvested, two grades of oil can be obtained i.e. leaf oil and flower oil. For getting high quality oil only the flowering tops are harvested. The harvested produce will be allowed to wilt in the field for 45 hours so as to reduce the moisture and also the bulkiness (Hamasaki et al., 1994; Joy et al., 2001).

\section{Importance of Basil}

Ocimum are important groups of aromatic and medicinal plants which yield many essential oils and aromatic chemicals and find diverse uses in perfumery and cosmetic industries as well as indigenous system of medicine. It is used in food industries and dental product (Prasad, et al,. 1986; Vieira and Simon 2000). Many medicinal and aromatic plants, including basil, are typically consumed without further processing after harvest (Banchio $e t$ al., 2008).

Among various Ocimum species, $O$. basilicum is commercially and extensively cultivated for essential oil production. Basil is grown in many countries of the world as spice, medicinal, and aromatic plant. The medicinal and aromatic properties of basil are associated with the presence of an essential oil that accumulates in large amount in its leaves and inflorescences. Basil oil is mixture of numerous compounds and its composition is extremely rich and varied. The major essential oil components of basil are: methyl chavicol, linalool, 1, 8cineole and methyl (Niederwireser 2001). Scientific research has investigated the health benefits associated with basil's essential oils. Different studies reveal the anti-viral, anti-microbial, antioxidant, and anti-cancer properties of the oils (Chiang et al., 2005; Bozin, et al., 2006). Moreover, basil oil and its pure components have antimutagenic activity (Stajković et al. 2007). Basil produces range of polyphenolic compounds including rosmarinic acid, a characteristic it shares with herbs in the genus Lamiaceae. Rosmarinic acid is a cinnamic acid derivative with potent antioxidant activity and known antiviral, antibacterial, and anti-inflammatory properties. In addition, several purple basil cultivars also contain anthocyanins which are powerful antioxidants, and the polyphenolic pigments responsible for the red and blue colors found in many plants (Nguyen and Niemeyer, 2008).

Traditionally, basil leaves are used in folk medicine as a remedy for a large number of diseases, including cancer, convulsion, diarrhea, epilepsy, gout, nausea, sore throat, toothaches, bronchitis coughs, constipation, warts, worms and kidney malfunction (Simon et al., 1990; Simon et al., 1999 and Duke et al., 2008). Hot tea of basil plant leaves is good for treating nausea, dysentery, and flatulence. Externally, basil formulations can be used for different skin infections such as treatment of acne, snake bites and insect stings (Khatri et al., 1995). Basil also possesses various beneficial effects, e.g., antiseptic, carminative, antimicrobial and antioxidative properties (Baranauskiene et al., 2003). The essential oil of basil is used as antifungal and insect-repelling agent (Reuveni et al., 1984; Werner 1995). The curative properties of basil result from the presence of essential oils, phenolic compounds, flavonoids (Nurzyńska-Wierdak et al. 2012) and other substances revealing anti-bacterial (Nour et al. 2009), anti-mycotic and antioxidant activities (Sekar et al. 2009).

\section{Factors Influencing Growth, Biomass and Oil Yield}

The principal interest in the cultivation of the crop is for its essential oil (EO) and maximization of economic yield returns. Basil crops may be grown solely for its essential oil and/or other products. Therefore, in the cultivation, basil plants should be grown to maximize the yield of both essential oil and fresh leaves. The growth and essential oil accumulation and composition of basil could be markedly affected by different factors such as environmental factors, physical and chemical properties of soil, seed source, plant age, parts of plant that which 
used for oil isolation, oil isolation method, genetic and agronomic practices (irrigation, fertilization, time of harvesting) etc. (Marotti et al., 1996;Shahram 2011).

\subsection{Environmental factors}

Performances of crop plants depend on temperature, solar radiation, moisture and soil fertility for their growth and nutritional requirements. Temperature plays an important role in plant growth and yield. Plants respond to temperature change in most of their metabolic activities such as photosynthesis respiration and transpiration (Murtagh, 1996). Climatic conditions during basil cultivation substantially affect the growth, flowering and chemical composition of the crop (Purkayasta and Nath, 2006; Nurzyska - Wierdak, 2007; Shatar et al. 2007). The authors reported that the number of leaves, fresh plant weight and concentration of basil essential oil increase under the influence of growing high temperatures $\left(30 / 25^{\circ} \mathrm{C}\right)$. They give this range of temperature and the 12-hour day as the optimal conditions for producing fresh basil herb.

Chang et al. (2008) reported d a distinct influence of solar radiation upon basil growth, as well as on quantity and quality of essential oil. The authors report that basil growth takes its best course under full sunlight; however, plants tolerate slight shading. The morphological and chemical variability of Ocimum basilicum L. creates great possibilities for growing different cultivars of this valuable herbal plant. The chemical composition of basil essential oil is dependent on genetic, ontogenetic, environmental factors and agro technical factors, such as cultivation method, harvest term, fertilization, or irrigation similarly as in other oil plants (Nurzyska Wierdak 2002; Zheljazkov et al. 2008; İpek et al. 2012).

\subsection{Effect of fertilizer on growth and yield of basil}

Growth and yield of basil, like other plants, depend upon the availability of all nutrients in the environment. The yield and quality is depends on macro- and micronutrient taken up (Zheljazkov et al. 2008).

\subsubsection{Effects of nitrogen fertilizer on growth, biomass and oil yield of basil}

Nitrogen $(\mathrm{N})$ is one of the basic nutrients used by plants to build many organic compounds, such as amino acids, peptides, proteins, enzymes, or nucleic acids (Ma and Shi 2011, Ma et al. 2012). Amino acids and enzymes play a key role in the biosynthesis of numerous compounds which are essential oil constituents (Koeduka et al. 2006). It is an important macronutrient necessary for the proper functioning of the plant. It has significant effect on yield amount and quality of oil plants.

Figure 1. Average total phenolic contents for Sweet Thai, Dark Opal (planted in summer and fall), and Genovese basil as a function of applied nitrogen level.

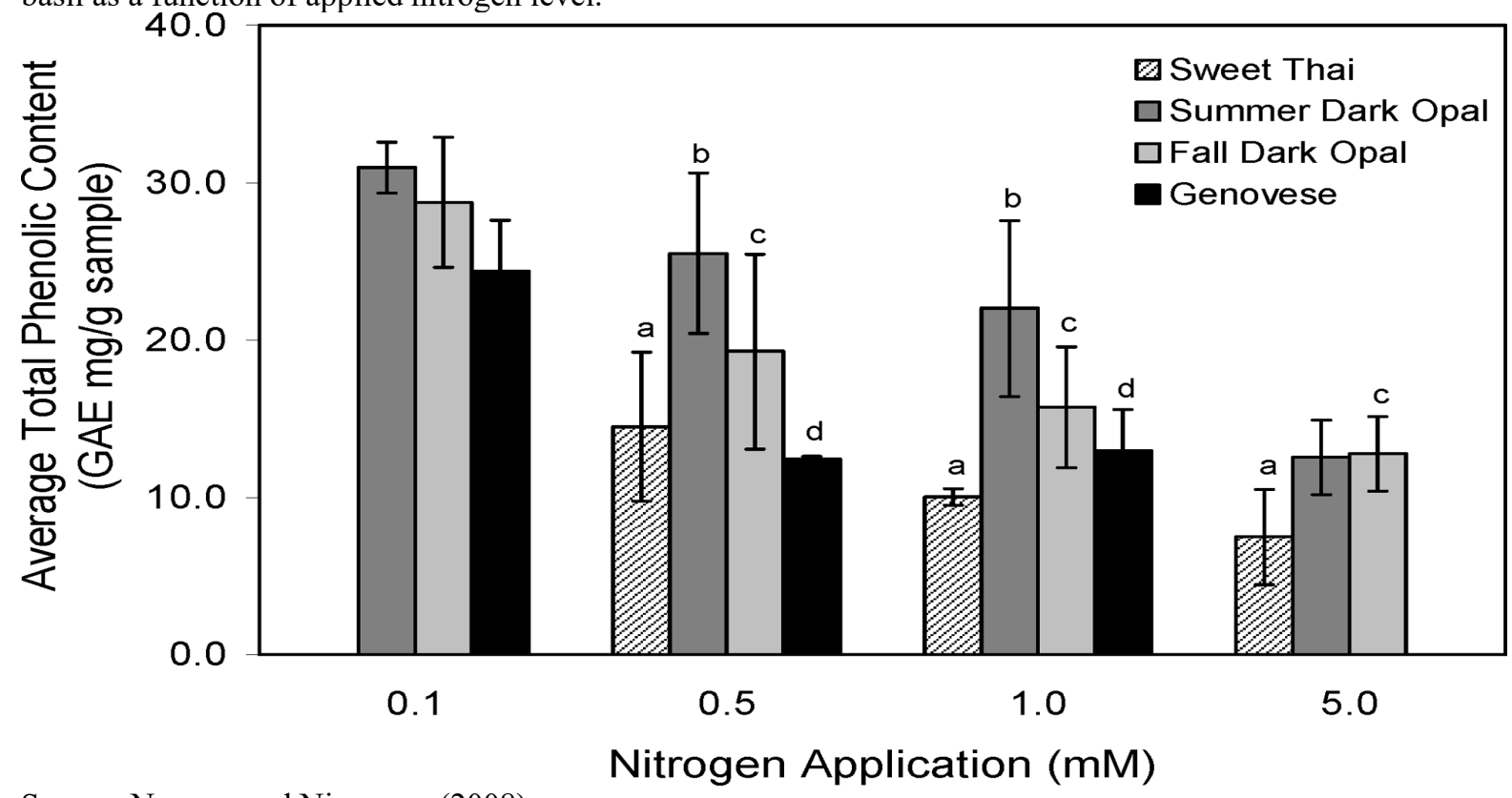

Source: Nguyen and Niemeyer (2008) 
Table 1. Interaction effect of $\mathrm{N}$ and $\mathrm{K}$ application on herb and oil yield of basil

\begin{tabular}{|c|c|c|c|c|c|c|}
\hline \multirow{3}{*}{$\begin{array}{l}\mathrm{N} \text { level } \\
\mathrm{N} \text { ha-1 year-1) }\end{array}$} & \multicolumn{3}{|c|}{ Herb yield (t ha-1) } & \multicolumn{3}{|c|}{ Oil yield (1 ha-1) (kg } \\
\hline & \multicolumn{3}{|c|}{$\begin{array}{c}\mathrm{K} \text { level } \\
\text { (kg K2O ha year) }\end{array}$} & \multicolumn{3}{|c|}{$\begin{array}{c}\text { K level } \\
\text { (kg K2O ha year) }\end{array}$} \\
\hline & 0 & 40 & 80 & 0 & 40 & 80 \\
\hline 0 & 4.37 & 2.81 & 2.81 & 23.2 & 15 & 15 \\
\hline 100 & 5.74 & 6.36 & 9.63 & 30.6 & 34 & 51.3 \\
\hline 200 & 6.29 & 7.62 & 9.58 & 33.6 & 40.7 & 51.1 \\
\hline $\mathrm{SE}+\mathrm{m}$ & & 1.28 & & & 6.6 & \\
\hline $\mathrm{CD}(\mathrm{P}=0.05)$ & & 2.63 & & & 14 & \\
\hline
\end{tabular}

Source: Rao et al., 2007

Nitrogen is required by plants in comparatively larger amounts than other elements. Nitrogen deficiency generally results in stunted growth and chlorite leaves caused by poor assimilate formation that leads to premature flowering and shortening of the growth cycle (Larimi et al 2014).

The presence of $\mathrm{N}$ in excess promotes development of the above ground organs with abundant dark green (high chlorophyll) tissues of soft consistency and relatively poor root growth (Lincoln and Edvardo, 2006). Nitrogen applied in the cultivation of herbal plants also stimulates the synthesis of other biologically active substances. Nitrogen contributes to the greatest extent to an increase in the biosynthesis of essential oil and its composition in numerous aromatic plant species (Renata, 2013). Essential oil yield and chemical composition of these plant species can be significantly depend on the rate of nitrogen. Arabaci and Bayram (2004) reported increase in fresh and dry basil herb yield, as well as in essential oil content and yield, under the conditions of $\mathrm{N}$ fertilizer application. The study of these authors showed the effect of applied $\mathrm{N}$ on essential oil composition of basil. Sifola and Barbieri (2006) reported that the basil cultivar had an impact on the effectiveness of $\mathrm{N}$ application in terms of increase in the amount of essential oil in the basil herb.

Study of Nguyen and Niemeyer (2008) showed that changes in the level of $\mathrm{N}$ fertilization during the growing period of basil had a significant impact on the production of phenolic compounds, in particular rosmarinic acid. Nitrogen application in growing basil contributes not only to an increase in essential oil content, but also increases the concentration of linalool and borneol in the oil, with a simultaneous decrease in the content of methyl chavicol and 1, 8-cineole (Taie et al., 2010). Studies of different researchers revealed that $\mathrm{N}$ application can increase essential oil yield of basil. Zheljazkov et al. (2008) report that maximum basil oil yield is obtained when $50-60 \mathrm{~kg}$ of $\mathrm{N}$ per hectare is applied; in addition, $\mathrm{N}$ significantly modifies the percentage of linalool, eugenol, bornyl acetate, and eucalyptol in basil essential oil.

Ali Sabah Alhasan et al 2020 reported that nitrogen fertilizer rates significantly affected basil growth and essential oil yield. According to the Authors the highest essential oil was recorded duet to application of moderate nitrogen fertilizer rates.

Figure 2. Effect of applying different nitrogen fertilizer rate on seed yield and essential oil yield

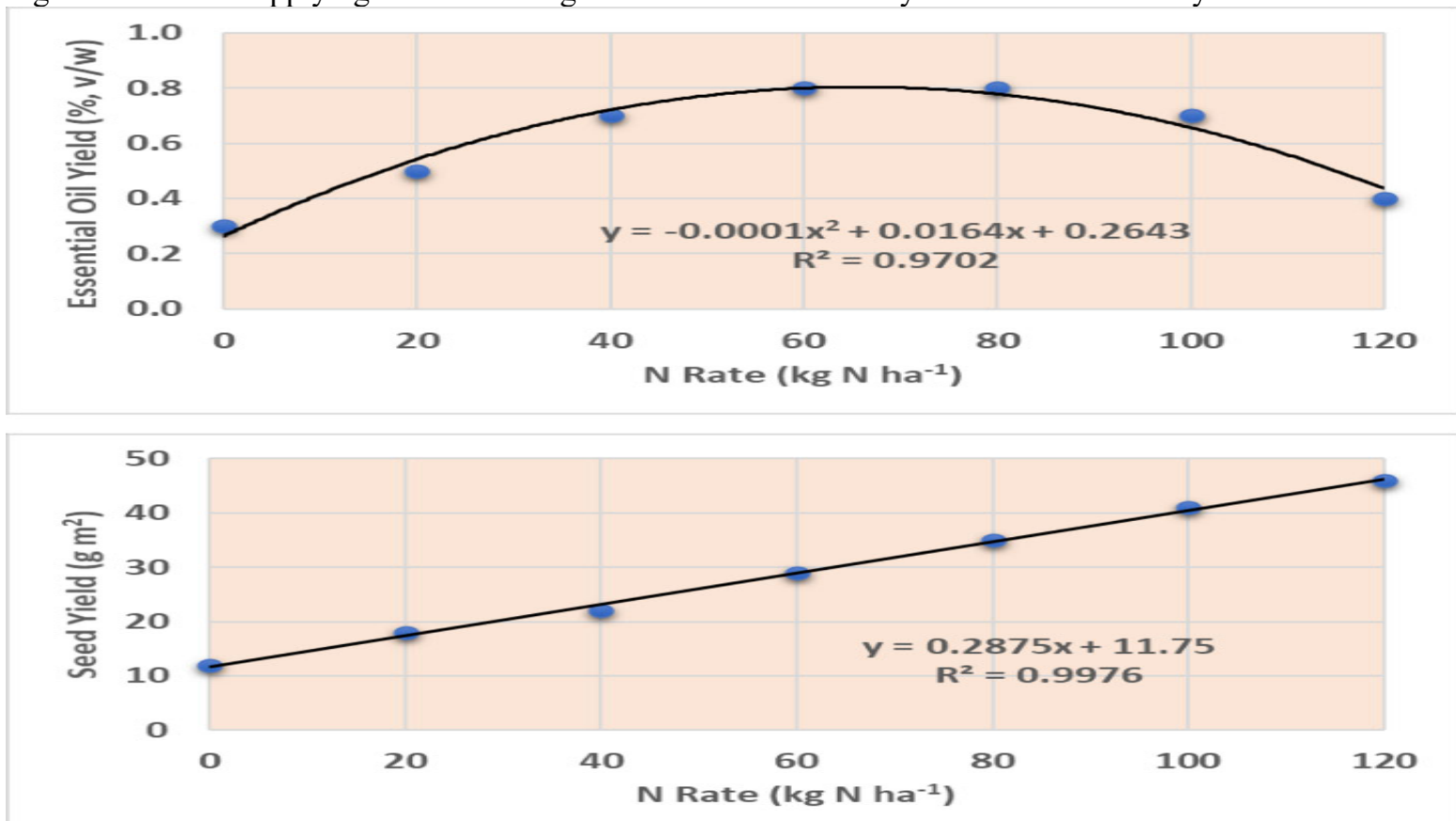

Source: Ali Sabah Alhasan et al 2020 
Rao et al. (2007) verified that elevated $\mathrm{N}$ availability (doses over $100 \mathrm{~kg} \mathrm{ha}^{-1}$ ) resulted in higher plant yield and essential oil content of basil. Alizadeh et al. (2010) reported that high correlation between shoot dry mass in relation to total dry matter weight, essential oils content, extraction efficiency of essential oils and phenolic compounds content of basil plants. Other nutrients, such as phosphorus, sulfur, calcium, magnesium and microelements, are also capable of changing essential oil yield and composition (Renata, 2013).

\subsubsection{Effects of phosphorous fertilizer on growth, biomass and oil yield of basil}

Plants need phosphorus (P) for growth, utilization of sugar and starch, photosynthesis, nucleus formation and cell division. Phosphorus compounds are involved in the transfer and storage of energy within plants. Energy from photosynthesis and the metabolism of carbohydrates is stored in phosphate compounds for later use in growth and reproduction. Plants require adequate $\mathrm{P}$ from the very early stages of growth for optimum crop production (Grant et al. 2005).

Crop removal of $\mathrm{P}$ may range from 3 to $30 \mathrm{~kg} \mathrm{P} \mathrm{ha}^{-1}$; therefore crop production will gradually deplete available soil $\mathrm{P}$ in the absence of $\mathrm{P}$ application. Conversely, excess $\mathrm{P}$ supply in the soil is a major environmental concern. Accumulation of $\mathrm{P}$ in the soil from applications of animal manures, biosolids or chemical fertilizer in excess of that taken up by the crop can increase the risk of $\mathrm{P}$ movement to surface and ground waters (Grant $e t$ al., 2005). A good supply of $\mathrm{P}$ has been shown to increase root growth (Marschner, 1999; Tisdale et al, 1990).

Ramezani and Rezaei 2009 conducted the study on effects of P fertilizer on basil. The result of study indicated the pattern of increasing of the essential oil by application of $\mathrm{P}$ treatments, essential oil content of basil in the study was significantly increased in different Potassium phosphate rates. The authors reported that, from the practical point of view, the increase in fresh and dry biomass and oil yield induced by $\mathrm{P}$ application has positive effects since the commercial value of basil and farmer incomes also depends on the amount of essential oil produced. According to Kapoor et al., (2004) addition of $\mathrm{P}$ fertilizer in the case of fennel, (Foeniculumvulgare Mill.) has also affected the yield and composition of essential oil.

\subsubsection{Effects of sulfur fertilizer on growth, biomass and oil yield of basil}

Sulfur (S) is essential plant macronutrient for crop production. It is increasingly recognized as the fourth major plant nutrient after nitrogen, phosphorus and potassium. The importance of $\mathrm{S}$ in agriculture is being increasingly emphasized and its role in crop production is well recognized (Jamal et al., 2005).

Sulfur has a broad spectrum of action that improves the general appearance of the plant, strengthens its natural defense, increases resistance to nutritional and climatic stresses and pest attack, and also influences positively other important aspects for essential oil production and development of shoots (Rezende, 2003). Sulfur is part of plant proteins as a component of the amino acids cysteine and methionine and coenzymes (Marschner, 1999).

Jamal et al. (2010) reported that in intensive crop rotations including oil crops, sulfur uptake can be very high, especially when the crop residue is removed from the field along with the product. According to these authors, the removing crop residue from the field with the product leads to $\mathrm{S}$ depletion in soil if the corresponding amount of $\mathrm{S}$ is not applied. Use of sulfur in crop production has received little attention for many years, because it has been considered that the atmosphere supplied the soil with adequate amounts of S (Jamal et al., 2010). Insufficient concentrations of sulfur reduce plant production in many parts of the world, and S deficit has been observed in soils and agricultural systems for the last few years due to several factors: depressed emission of $\mathrm{S}$ to atmosphere, low concentration of $\mathrm{S}$ in most of mineral fertilizers, which does not balance the loss of S caused by its uptake by crops, low level of organic fertilization and migration of sulfate to deeper soil horizons and ground water (Zhao et al. 1999, Fismes et al. 2000, Scherer 2001, McGrath et al. 2003, Walker and Dawson 2003, Matula 2004).

Different studies conducted on the effects of sulfur on basil crop. The study revealed that, an increased amount of S causes a rise in production of essential oil and eucalyptol in basil oil (Zheljazkov et al. 2008) 
Figure. 3. Oil production as a function of sulfur fertilization at three locations

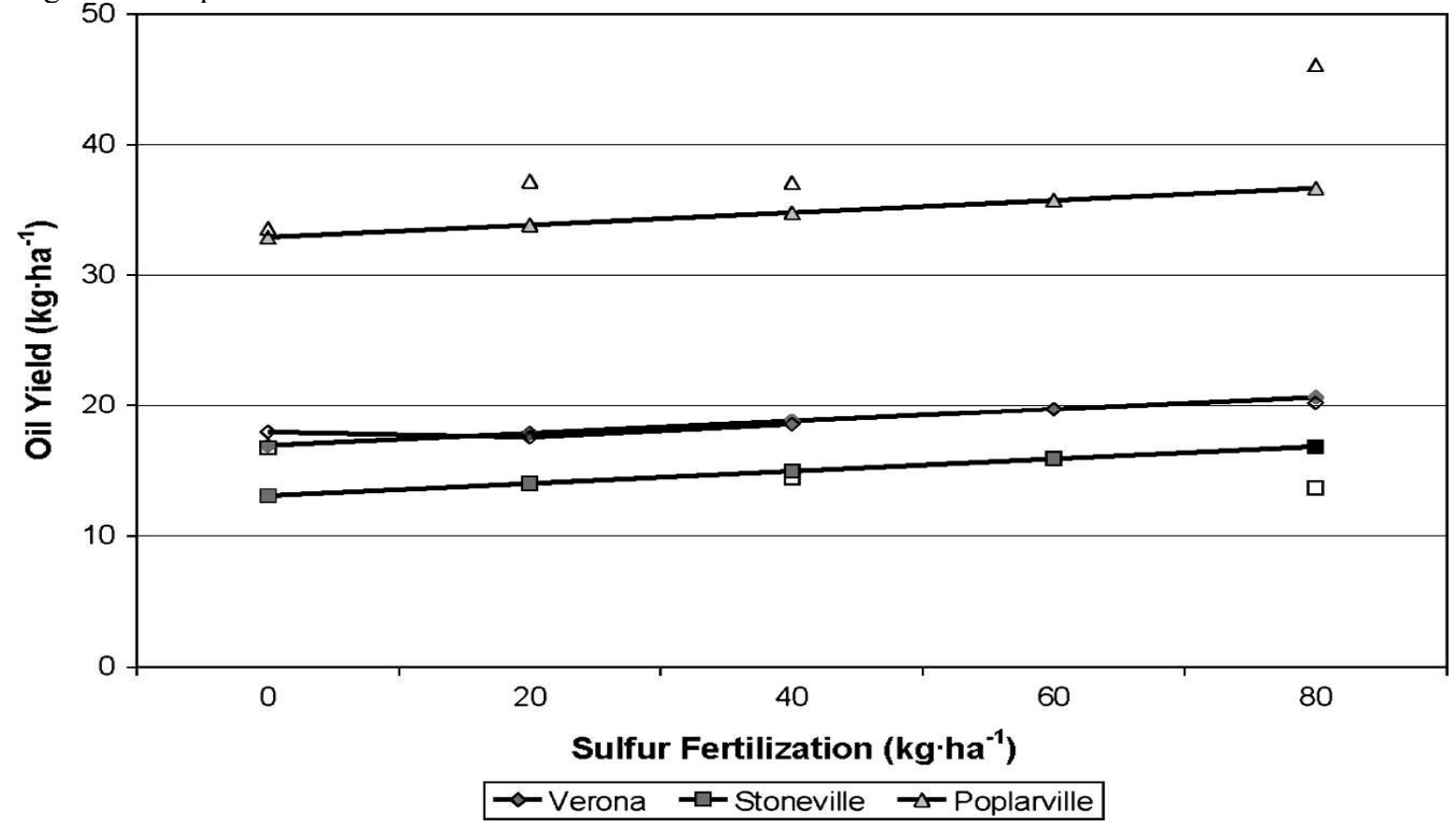

Source: Zheljazkov et al. 2008.

The authors concluded that since the result of study showed strong response of basil oil yield to $\mathrm{S}$, further research with $\mathrm{S}$ application rates and intermediate $\mathrm{N}$ background may be needed to estimate the optimal basil yield and compositional response to nitrogen and sulfur.

Sulfur is best known for its role in the formation of amino acids methionine $(21 \% \mathrm{~S})$ and cysteine $(27 \% \mathrm{~S})$; synthesis of proteins and chlorophyll; oil content of the seeds and nutritive quality of forages (Tandon, 1986; Jamal et al., 2005). Sulfur is especially important for oil crops. Study indicated that, the amount of S required to produce one ton of seed is about $3-4 \mathrm{~kg} \mathrm{~S}$ for cereals, $8 \mathrm{~kg} \mathrm{~S}$ for legume crops and $12 \mathrm{~kg} \mathrm{~S}$ for oil crops (Scherer, 2009). In general, this author concluded that oil crops require about the same amount of S as, or more than, phosphorus for high yield and product quality.

An insufficient S supply can affect yield and quality of the crops; caused by the S requirement for protein and enzyme synthesis as well it is a constituent of amino acids and methionine. According to Marschner (1999), sulfur deficiency could reduce $\mathrm{N}$ uptake, potential crop yield, and the quality of plants. To overcome the problems associated with $\mathrm{S}$ deficiency a number of $\mathrm{S}$ containing fertilizers as well as other $\mathrm{S}$ containing byproducts from industrial processes are available (Jamal et al., 2010).

\section{Conclusion}

Basil (Ocimum basilicum L) is a crop grown for its aromatic properties, while the green leaves are used fresh or dried used as an aromatic spice for flavoring of dishes, salads, stews, sausages and other food. The oil of basil also used for flavoring of food stuffs, confectionery, condiments, and in toiletry products. Performances of crop plants depend on temperature, solar radiation, moisture and soil fertility for their growth and nutritional requirements. Fertilizer is one of the important factor affect the growth and yield of basil. Generally, basil (Ocimum basilicum $\mathrm{L}$ ) is a medicinal and aromatic crop, easy to grow and use as herb and essential oil.

\section{References}

Ali Sabah Alhasan et al 2020 IOP Conf. Ser.: Earth Environ. Sci. 553012044

Alizadeh, A., Orteza, K.M; Javidnia. K., Firuzi, O., Tafazoli, E and Khalighi, A. 2010. Effects of fertilizer on yield, essential oil composition, total phenolic content and antioxidant activity in Saturejahortensis L. (Lamiaceae) cultivated in Iran. Journal of Medicinal Plants Research, 4: 33-40.

Arabaci, O., Bayram, E. 2004. The effect of nitrogen fertilization and different plant densities on some agronomic and technologic characteristic of Ocimumbasilicum L. (Basil). Journal of Agronomy, 3 (4): 255262

Banchio, E., Bogino, P.C., Zygadlo, J. and Giordano, W. 2008. Plant growth promoting rhizobacteria improve growth and essential oil yield in Origanummajorana L. Biochemical Systematics and Ecology, 36(10) : $766-771$.

Baranauskienè, R., Venskutonis, P.R., Viškelis, P. and Dambrauskienė, E. 2003. Influence of nitrogen fertilizers 
on the yield and composition of thyme (Thymus vulgaris). Journal of Agricultural and Food chemistry, 51(26) : 7751-7758.

Bozin, B., Mimica-Dukic, N., Simin, N. and Anackov, G. 2006.Characterization of the volatile composition of essential oils of some Lamiaceae spices and the antimicrobial and antioxidant activities of the entire oils. Journal of agricultural and food chemistry, 54(5): 1822-1828.

Chang, X., Alderson, P.G. and Wright, C.J. 2008. Solar irradiance level alters the growth of basil (Ocimumbasilicum L.) and its content of volatile oils. Environmental and Experimental Botany, 63(1-3) : 216-223.

Darrah, H.H. 1980. The cultivated basils. Buckeye Printing Company, Independence, MO.

Duke, J.A., Bogenschutz-Godwin, M.J., Du Cellier, J., Duke, P.A.K. 2008. Handbook of Medicinal Herbs, 2nd ed.; CRC Press: Boca Raton, FL, USA, 60-62.

Fismes, J., Vong, P.C., Guckert, A. and Frossard, ETHIOPIAN. 2000. Influence of sulfur on apparent N-use efficiency, yield and quality of oilseed rape (Brassica napus L.) grown on a calcareous soil. European Journal of Agronomy, 12(2): 127-141

Grant, C., Bittman, S., Montreal, M., Plenchette, C. and Morel, C. 2005. Soil and fertilizer phosphorus: Effects on plant P supply and mycorrhizal development. Canadian Journal of Plant Science, 85(1):3-14.

Hamasaki, R.T., Valenzuela, H.R., Tsuda, D.M. and Uchida, J.Y., 1994. Fresh basil production guidelines for Hawaii. Research Extension Series 154-Hawaii Institute of Tropical Agriculture and Human Resources

Heath, H.B. 1981: Source book of flavors. AVI. West port CT:222- 223.

Ipek, A., GÜRBÜZ, B., BINGÖL, M.Ü., GEVEN, F., AKGÜL, G., Rezaeieh, K.A.P. and COŞGE, B., 2012. Comparison of essential oil components of wild and field grown Salvia cryptanthaMontbert\&Aucher ex Benthan, in Turkey. Turkish Journal Of Agriculture and Forestry, 36(6) : 668-672.

Jamal, A., Fazli, I.S., Ahmad, S., Abdin, M.Z. and Yun, S.J. 2005. Effect of sulphur and nitrogen application on growth characteristics, seed and oil yields of soybean cultivars. Korean Journal of Crop Science, 50(5) : 340.

Jamal, A., Moon, Y.S. and ZainulAbdin, M. 2010. Sulphur-a general overview and interaction with nitrogen. Australian Journal of Crop Science, 4(7) : 523.

Javanmardi, J., Khalighi, A., Kashi, A., Bais, H.P. and Vivanco, J. M. 2002. Chemical characterization of basil (Ocimumbasilicum L.) found in local accessions and used in Otraditional medicines in Iran. Journal of agricultural and food chemistry, 50(21) : 5878-5883.

Joy, P.P., Thomas, J., Mathew, S., Jose, G. and Joseph, J. 2001.Aromatic plants.Tropical Horticulture Vol. 2. (eds. Bose, T.K., Kabir, J., Das, P. and Joy, P.P.). Naya Prokash, Calcutta

Kapoor, R., Giri, B. and Mukerji, K.G. 2004. Improved growth and essential oil yield and quality in Foeniculumvulgare mill on mycorrhizal inoculation supplemented with P-fertilizer. Bioresource Technology, 93(3) : 307-311.

Khatri, L.M., Nasir, M.K.A., Saleem, R. and Noor, F. 1995. Evaluation of Pakistani sweet basil oil for commercial exploitation. Pakistan Journal of Scientific and Industrial Research, 38 : 281-282.

Koeduka, T., Fridman, E., Gang, D.R., Vassão, D.G., Jackson, B.L., Kish, C.M., Orlova, I., Spassova, S.M., Lewis, N.G., Noel, J.P. and Baiga, T.J. 2006. Eugenol and isoeugenol, characteristic aromatic constituents of spices, are biosynthesized via reduction of a coniferyl alcohol ester. Proceedings of the National Academy of Sciences, 103(26) : 10128-10133.

Kumar, J. 2014. Cultivation of Ocimum. ICAR - Directorate of Medicinal and Aromatic Plants Research. Boriavi, Anand - 387 310, Gujarat www.dmapr.org.in. Accessed on May 15/05/2017

Larimi, S.B., Shakiba, M., Mohammadinasab, A.D. and Vahed, M.M. 2014. Changes in nitrogen and chlorophyll density and leaf area of sweet basil (Ocimumbasilicum L.) affected by biofertilizer and nitrogen application. International Journal of Biosciences (IJB), 5(9) : 256-265.

Lincoln, T. and Edvardo, Z. 2006. Assimilation of mineral nutrition. In: Plant Physiology (4th Edition), Sinaur Associates, Inc. Pub. Sunderland, 705.

Ma, L. and Shi, Y. 2011. Effects of potassium fertilizer on physiological and biochemical index of Stevia rebaudiana Bertoni. Energy Procedia, 5 : 581-586

Ma, L., Ren, G.X. and Shi, Y. 2012. Effects of potassium fertilizer on diurnal change of photosynthesis in Stevia rebaudiana Bertoni. Advanced Materials Research (Vol. 343 : 1087-1091).Trans Tech Publications.

Marotti, M., Piccaglia, R., Giovanelli, E. 1996. Differences in essential oil composition of basil (Ocimumbasilicum L.) Italian cultivars related to morphological characteristics. Journal of Agriculture and Food Chemistry. 44:3926-3929.

Marschner, H. 1999. Mineral nutrition of higher plants. Academic Press, London, UK.

McGrath, S.P., Zhao, F.J. and Blake-Kalff, M.M. 2003. History and outlook for sulphur fertilizers in Europe. Fertilizers Fertilization, 2(15) : 5-27.

Murtagh, G. J. 1996. Month of harvest and yield components of tea tree. I. Biomass. Australian Journal of 
Agricultural Research, 47(5) : 801-815.

Nguyen, P.M. and Niemeyer, E.D., 2008. Effects of nitrogen fertilization on the phenolic composition and antioxidant properties of basil (Ocimum basilicum L.). Journal of Agricultural and Food Chemistry, 56(18) : 8685-8691.

Niederwieser, J.G. 2001. Guide to hydroponic vegetable production. 2nd ed. Pretoria: Agricultural Research Council, Roodeplaat, Vegetable and Ornamental Plant Institute; 140

Nour, A.H., Elhussein, S.A., Osman, N.A., Ahmed, N.E., Abduelrahman, A.A. and Yusoff, M.M. 2009. Antibacterial activity of the essential oils of Sudanese accessions of basil (Ocimum basilicum L.). Journal of Applied Sciences, 9(23), 4161-4167.

Nurzynska-Wierdak, R. 2002. Evaluation of growth and yield of two forms of sweet basil grown from seeds and transplants. Folia Horticulturae (Poland).

Nurzyńska-Wierdak, R., Rożek, E., Dzida, K. and Borowski, B. 2012. Growth response to nitrogen and potassium fertilization of common basil (Ocimum basilicum L.) plants. Acta Scientiarum Polonorum Hortorum Cultus, $11: 275-288$.

Prasad, G., Kumar, A., Singh, A.K., Bhattacharya, A.K., Singh, K. and Sharma, V.D., 1986. Antimicrobial activity of essential oils of some Ocimum species and clove oil. Fitoterapia, 57 : 429-432.

Purkayastha, J. and Nath, S.C. 2006. Composition of the camphor-rich essential oil of Ocimumbasilicum L. native to Northeast India. Journal of Essential Oil Research, 18(3) : 332-334

Putievsky, E. 1983. Temperature and day length influences on the growth and germination of sweet basil and oregano. Journal of horticultural science, 58(4) : 583-587.

Ramezani, S., Rezaei, M.R. and Sotoudehnia, P. 2009. Improved growth, yield and essential oil content of basil grown under different levels of phosphorus sprays in the field. Journal of Applied Environmental and Biological Sciences 3 : 296-101.

Renata Nurzyska-wierdak. 2013. Does mineral fertilization modify essential oil content and chemical composition in medicinal plants? Acta Scientiarum Polonorum-Hortorum Cultus, 12(5) : 3-16.

Reuveni, A.F. and Putievsky, E. 1984. Fungistatic activity of essential oils from Ocimumbasilicum chemotypes. Journal of Phytopathology, 110(1) : 20-22.

Rezende, J.M. 2003. Cartilha de homeopatia: Instruçõespráticasgeradasporagricultoressobre o uso da homeopatia no meio rural. Viçosa: ProdutoresOrgânicos da Região da VertentedoCaparaó - Minas Gerais.

Scherer, H.W. (2001): Sulphur in crop production - invited paper. European Journal of Agronomy. 14: 88-111

Sekar, K., Thangaraj, S., Saravana, B.S, Harisaranraj, R. and Suresh, K. 2009. Phytochemical constituent and antioxidant activity of extract from the leaves of Ocimumbasilicum L. Journal of Phytology, 1:408-413.

Shahram, S. (2011). Effect of Nitrogen, Phosphorous and Potassium on Growth, Essential Oil and Total Phenolic Content of Garden Thyme (Thymus vulgaris L.). Advances in Environmental Biology, 5(4): 699-703

Shatar, S., Altanstetseg, Sh., Sarnali, I., Zol -jargal, D., Thang, T.D and Dung, N.X. 2007. Chemical composition of the essential oil of Ocimumbasilicum cultivated in Mongolian Desert-Gobi. Chem. Natural Comp. 43 (6): 726-727.

Sifola, M.I. and Barbieri, G., 2006. Growth, yield and essential oil content of three cultivars of basil grown under different levels of nitrogen in the field. Scientia Horticulturae, 108(4) : 408-413.

Simon, J. E., Quinn, J. and Murray, R.G. 1990. Basil: a source of essential oils. Advances in new crops, 484-489.

Simon, J.E., Morales, M.R., Phippen, W.B., Vieira, R.F. and Hao, Z. 1999. Basil: a source of aroma compounds and a popular culinary and ornamental herb. Perspectives on new crops and new uses, 499-505.

Simon, J.E., Morales, M.R., Phippen, W.B., Vieira, R.F. and Hao, Z. 1999. Basil: a source of aroma compounds and a popular culinary and ornamental herb. Perspectives on new crops and new uses, 499-505.

Stajković, O., Berić-Bjedov, T., Mitić-Ćulafic, D., Stankovic, S., Vuković-Gačić, B., Simić, D. and KneževićVukčevič, J., 2007. Antimutagenic Properties of Basil (Ocimumbasilicum L.) in Salmonella typhimurium TA100. Food Technology \& Biotechnology, 45(2).

Stajković, O., Berić-Bjedov, T., Mitić-Ćulafic, D., Stankovic, S., Vuković-Gačić, B., Simić, D. and KneževićVukčevič, J., 2007. Antimutagenic Properties of Basil (Ocimumbasilicum L.) in Salmonella typhimurium TA100. Food Technology \& Biotechnology, 45(2).

Taie, H.A.A., Salama, Z.A.E.R. and Radwan, S., 2010. Potential activity of basil plants as a source of antioxidants and anticancer agents as affected by organic and bio-organic fertilization. Notulae Botanicae Horti Agrobotanici Cluj-Napoca, 38(1) : 119.

Tandon, H.L.S. 1986. Sulphur: Research and agricultural production in India (No. REP-3982. CIMMYT).

Tisdale, S. L., Nelson, W.L., Beaton, J.D. and Halven, J. 1990. Soil Fertility and Fertilizer Macmillan Pub.Co. New York.

Tiwari, R. J. and Banafar, R.N.S. 1995. Application of nitrogen and phosphorus increases seed yield and essential oil of coriander. Indian Cocoa, Arecanut and Spices Journal, 19(2) : 51-55.

Vieira, R.F. and Simon, J.E., 2000. Chemical characterization of basil (Ocimum spp.) found in the markets and 
used in traditional medicine in Brazil. Economic botany, 54(2) : 207-216.

Walker, K. and Dawson C. 2003: Sulphur fertilizer recommendations. Fertilizers Fertilization, 3: 71-89

Werner R.A. 1995. Toxicity and repellency of 4-allylanisole and monoterpenes from white spruce and tamarack to the spruce beetle and Eastern larch beetle(Coleopterascolytidae). Environ. Entomology. 24:372-379.

Zhao, F.J., Hawkesford, M.J. and McGrath, S.P. 1999. Sulphur assimilation and effects on yield and quality of wheat. Journal of Cereal Science, 30(1) : 1-17.

Zheljazkov, V.D., Cantrell, C.L., Ebelhar, M.W., Rowe, D.E. and Coker, C. 2008. Productivity, oil content, and oil composition of sweet basil as a function of nitrogen and sulfur fertilization. Horticultural Science, 43(5) : 1415-1422.

Zheljazkov, V.D., Cantrell, C.L., Ebelhar, M.W., Rowe, D.E. and Coker, C. 2008. Productivity, oil content, and oil composition of sweet basil as a function of nitrogen and sulfur fertilization. Horticultural Science, 43(5) : 1415-1422. 